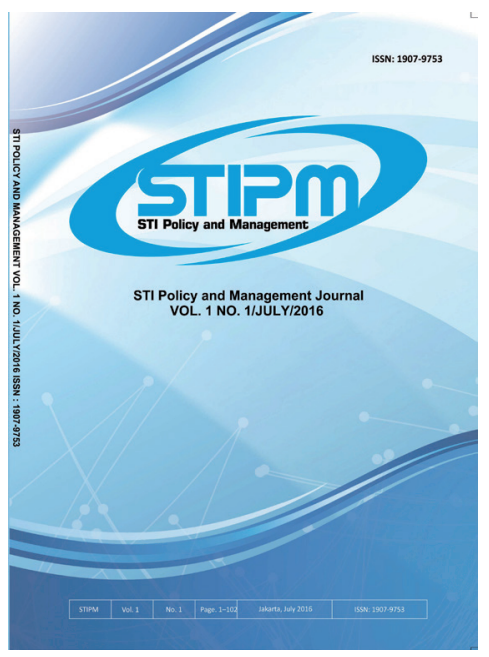

Journal of STI Policy and Management

Publication details, including instructions for authors and subscription information: http://www.stipmjournal.org/

\title{
Technology and Standardization Strategies related to the Diffusion of Smart Houses: The Case of ECHONET in Japan
}

Kumiko Miyazaki ${ }^{\text {a }}$, Kentaro Nishida ${ }^{\text {b }}$

${ }^{a}$ Tokyo Institute of Technology, Japan

${ }^{\mathrm{b}}$ The University of Tokyo, Japan

Version of record first published: 15 July 2016

To cite this article: Miyazaki, K. \& Nishida, K. (2016). Technology and Standardization Strategies related to the Diffusion of Smart Houses: The Case of ECHONET in Japan. Journal of STI Policy and Management,

$1(1), 17-27$

To link to this article: http://dx.doi.org/10.14203/stipm.v1i1

ISSN 1907-9753 (Print); ISSN 2502-5996 (online)

Accreditation Number: 622/AU3/P2MI-LIPI/03/2015

Full terms and conditions of use: https://creativecommons.org/licenses/by-nc-sa/4.0/

You are free to:

- Share : copy and redistribute the material in any medium or format

- Adapt : remix, transform, and build upon the material

- The licensor cannot revoke these freedoms as long as you follow the license terms.

Under the following terms:

Attribution - You must give appropriate credit, provide a link to the license, and indicate if changes were made. You may do so in any reasonable manner, but not in any way that suggests the licensor endorses you or your use.

NonCommercial - You may not use the material for commercial purposes.

ShareAlike - If you remix, transform, or build upon the material, you must distribute your contributions under the same license as the original.

No additional restrictions - You may not apply legal terms or technological measures that legally restrict others from doing anything the license permits.

Notices:

- You do not have to comply with the license for elements of the material in the public domain or where your use is permitted by an applicable exception or limitation.

- No warranties are given. The license may not give you all of the permissions necessary for your intended use. For example, other rights such as publicity, privacy, or moral rights may limit how you use the material.

- If you copy the dataset merely to extract the uncopyrightable data elements would not need permission to do so. However, if you republish the full dataset or using the copyrightable data layers require a permission from PAPPIPTEK-LIPI. 


\section{JOURNAL OF STI POLICY AND MANAGEMENT}

Volume 1 No. 1 July 2016

\section{LIST OF CONTENTS}

Innovation System Reform in Indonesia and Vietnam: A new Role for Universities?

Erik Baark.

Technology and Standardization Strategies related to the Diffusion of Smart Houses: The Case of ECHONET in Japan

Kumiko Miyazaki, Kentaro Nishida

Intellectual Property Creation of Japanese Companies in China and Thailand

Masayuki Kondo.

Technological Capability Upgrading and Entrepreneurship: Case Study of Selected Indonesian Fish Processing Companies

Erman Aminullah, Trina Fizzanty, Galuh S. Indraprahasta, and Indri J. Asmara

Influential Factors of Evidence-Based Energy Policy-making: Government Regulation on Targeting Renewable Energy in Indonesia

Wati Hermawati, Prakoso Bhairawa Putera, Dudi Hidayat, and Ishelina Rosaira P.

Finding the Most Efficient Technology Transfer Route Using Dijkstra Algorithm to Foster Innovation: The Case of Essential Oil Developments in the Research Center for Chemistry at the Indonesian Institute of Sciences

Arief A. R. Setiawan, Anny Sulaswatty, and Agus Haryono 


\title{
in STI POLICY AND MANAGEMENT



\section{Technology and Standardization Strategies related to the Diffusion of Smart Houses: The Case of ECHONET in Japan}

\author{
Kumiko Miyazaki ${ }^{\text {a,*}}$, Kentaro Nishida ${ }^{\text {b }}$ \\ ${ }^{a}$ Tokyo Institute of Technology, Japan \\ ${ }^{b}$ The University of Tokyo, Japan
}

\begin{tabular}{|c|c|}
\hline ARTICLE INFO & ABSTRACT \\
\hline $\begin{array}{l}\text { Article History: } \\
\text { Received : } 27 \text { January } 2016 \\
\text { Revised : } 21 \text { March } 2016 \\
\text { Accepted : } 21 \text { June } 2016 \\
\text { Available online : } 15 \text { July } 2016\end{array}$ & $\begin{array}{l}\text { In this paper, an analysis is made of the technology and standardization } \\
\text { strategies regarding ECHONET and KNX, which are the de jure } \\
\text { standards for smart houses in Japan and Europe. Eleven interviews with } \\
\text { the main actors related to the ECHONET Consortium and KNX were } \\
\text { conducted. Three research questions were set. What are the technology }\end{array}$ \\
\hline $\begin{array}{l}\text { Keywords: } \\
\text { Smart house } \\
\text { Technology strategy } \\
\text { Standardization strategy } \\
\text { IoT } \\
\text { ECHONET }\end{array}$ & $\begin{array}{l}\text { strategy related concerns of the main actors related to ECHONET? } \\
\text { What are the issues related to the diffusion of smart houses? What } \\
\text { are the underlying strengths and weaknesses of ECHONET when } \\
\text { compared with KNX? The analyses showed that the strategies of the } \\
\text { various actors towards the diffusion of smart houses were different, } \\
\text { based on their different perspectives, visions and competences. A } \\
\text { comparison between Japanese and European case highlighted the } \\
\text { different standardization strategies and areas of focus. The main } \\
\text { bottlenecks towards the diffusion of smart houses were identified. } \\
\text { C2016 PAPPIPTEK-LIPI All rights reserved }\end{array}$ \\
\hline
\end{tabular}

\section{INTRODUCTION}

\section{A. Background and objectives of this study}

In recent years, interest in smart houses has been growing in many parts of the world in pursuit of greater energy efficiency, more convenience and better safety. The efficient use of energy is becoming quite important. Consumption can be managed by intelligent control and monitoring of all related products and appliances such as

\footnotetext{
* Corresponding Author. Tel: + 81-3-5734-3323

E-mail: miyazaki.k.ae@m.titech.ac.jp (K. Miyazaki), nishida-k@ip.civil.t.u-tokyo.ac.jp (K. Nishida)
}

air conditioners, windows, blinds, shutters, and lightings. Smart houses usually refer to houses with features of Home Energy Management Systems (HEMS), Home Automation (HA) or both. Various definitions of smart houses may exist but they have a common characteristic: through linking various modules components, electric appliances, technologies and sensors, smart houses aim to offer an innovative integrated solution to provide a level of smartness that has not existed in traditional houses. HEMS include energy saving, energy generation as well as energy storage systems, while HA includes technologies and services which lead to better convenience and safety through automation. As 
an example of HA, Apple's Homekit in the US allows an iPhone or iPad to be used as to control home electric appliances ${ }^{1}$. Other types of application services that may be available in a smart house include, energy services, home amenities, healthcare services, security services, remote appliance maintenance services or mobile services. However, the diffusion of smart houses has been quite slow, as smart houses account for less than $0.2 \%$ of total households in Japan ${ }^{2}$. According to the Ministry of Economy, Trade and Industry (METI), the market for smart houses is expected to reach 3.5 trillion yen in Japan and 12 trillion yen worldwide by $2020^{3}$.

In smart houses, the modules, appliances and devices must be interconnected to function as a whole integrated system, so that standards become a critically important issue. At present, in Europe, USA and Japan, de jure standards related to smart houses exist. In Japan, ECHONET Lite is the standard proposed by the ECHONET Consortium ${ }^{4}$. In Europe, the Belgium-based KNX Association is the standards body and has been promoting KNX, and in the US, the Zigbee Alliance has been promoting Smart Energy Profile 2.0 (SEP 2.0) $)^{5,6}$. In a smart house, various modules, devices and technologies have to be integrated, so there are many actors involved, such as consumer electronics makers, telecommunications operator, utility companies, house makers etc. These companies have been part of the standard setting process.

Miyazaki \& Oshima (2010) carried out an empirical analysis of technology strategies related to the standardization process in the mobile wireless field, focusing on factors affecting the companies' choice of technologies to support and how strategies vary over the three before/during/ after phases of the standardization process. In the mobile wireless field standardization, companies can take the option to not support a standard that does not benefit them anymore, but in the smart house standardization they can hardly take that option because there are only three global de jure standardization organizations which are SEP 2.0, KNX and ECHONET.

\section{B. Methodology}

In this paper, an analysis is made of the technology strategies used by the main actors related to ECHONET.

In order to prepare for this research, the authors collected information on ECHONET, KNX and SEP. One of the authors became a member of the ECHONET Consortium as an individual academic researcher and the authors visited various events such as Smart Grid EXPO 2014, HEMS Certification Centre, Smart Community Summit 2014 and the ECHONET Forum. Interviews were carried out with key personnel in the industry, government, local government and other institutions related to ECHONET. Each of the eleven interviews lasted more than two hours and were recorded with permission. Questions were sent in advance to the interviewees, with the ability to ask additional questions during the interviews (Table 1).

In order to make a comparison, several individuals related to KNX in Germany and Japan were also interviewed. One of the authors spent three months at a leading university in Germany in order to conduct studies, including field study. The first two interviews shown in Table 2 were carried out by Skype and telephone.

This paper discusses findings for the following three points:

1. What are the technology strategy related concerns of the main actors related to ECHONET?

2. What are the issues related to the diffusion of smart houses?

3. What are the underlying strengths, weaknesses of ECHONET compared with KNX?

The paper is structured as follows. Section II outlines the methodology used in the paper. This is followed by a discussion of ECHONET Lite and KNX. In the main part of the paper, the strategies and the perspectives toward ECHONET adopted by the main actors, Toshiba, NEC, METI and Yokohama City, are discussed. Finally, conclusions are drawn from the paper and some suggestions to speed up the diffusion of smart houses are made. 


\section{ANALYTICAL FRAMEWORK}

\section{Theoretical background}

According to Porter \& Heppelmann (2014), smart, connected products offer exponentially expanding opportunities for new functionality, greater reliability, much higher product utilization and capabilities that cut across and transcend traditional product boundaries. These new types of products alter the industry structure and the nature of competition, exposing companies to new competitive opportunities and threats. They point out that what makes smart, connected products fundamentally different is not the internet, but the changing nature of the 'things'. They propose that smart, connected products offer new functionality and capabilities that may be grouped into four categories: 1) monitoring; 2) control; 3) optimization; and 4) autonomy. For example, smart products are able to learn about their environment, diagnose their needs and adapt to users' preferences. They can facilitate remote monitoring, operation in remote locations.
While a smart house may consist of an integration of various modules - elements such as sensors, smart meter and IT- a smart house can be considered as an element of a complex system, which might consist of a smart community or a smart city. Complexity may be defined as the combination of elements and nuances produced (the number of elements and their relationships), and the characteristics of actors which are related to their values, interests, motives, capabilities etc. Complexity is seen as arising from the difference of perspectives of organizations (Miyazaki \& Kijima, 2000). In the initial phase of the diffusion of smart houses, we have to consider not only technological innovations but also social change, as well as the diverse actors' perspectives and their strategies. The actors may include government, local government, house manufacturers, consumer electronics manufacturers, HEMS (Home Energy Management Systems) manufacturers, solar panel manufacturers and standard organizations.

Table 1.

A summary of the interviews (for ECHONET)

\begin{tabular}{|c|c|c|}
\hline Actor & Interviewee(s) & Main agenda \\
\hline Sony & $\begin{array}{l}\text { Sony CSL(Computer Science Lab) Associate } \\
\text { Researcher }\end{array}$ & The development of OPENECHO and Kadecot \\
\hline $\begin{array}{l}\text { Kanagawa Univ. } \\
\text { Prof. }\end{array}$ & The Chair of METI's HEMS Taskforce & $\begin{array}{l}\text { The strategy of ECHONET Consortium. METI's } \\
\text { policy }\end{array}$ \\
\hline TOSHIBA & ECHONET Consortium Director & $\begin{array}{l}\text { Toshiba's home appliances for smart houses. } \\
\text { Strengths of ECHONET }\end{array}$ \\
\hline \multirow[t]{3}{*}{$\mathrm{NEC}$} & Smart Energy Manager & \multirow[t]{3}{*}{$\begin{array}{l}\text { NEC's strategy towards the diffusion of smart } \\
\text { house }\end{array}$} \\
\hline & Telecom Carrier Planning Manager & \\
\hline & No. 2 Carrier Service Manager & \\
\hline Hitachi & Smart City Project Manager & Strategies towards a global standard \\
\hline NEC & Telecom Carrier Business Manager & HEMS as a cloud service \\
\hline \multirow[t]{2}{*}{ Yokohama City } & Yokohama City Global Warming & HEMS demonstration project in Yokohama \\
\hline & Unit Manager & \\
\hline METI & $\begin{array}{l}\text { Information Economy Division, Commerce } \\
\text { and Information Policy Bureau }\end{array}$ & $\begin{array}{l}\text { METI's policies towards smart grids and diffusion } \\
\text { of smart houses }\end{array}$ \\
\hline
\end{tabular}

Table 2.

A Summary of the interviews (for KNX)

\begin{tabular}{lll}
\hline Actor & Interviewee(s) & Main agenda \\
\hline Rockethome & Rockethome, CEO & Strategies towards smart meters and home automation in Germany \\
Siemens & KNX Chairman & Strategies of KNX, Siemens business strategies \\
KNX Japan, Fujitsu General & KNX Japan & KNX Japan's strategies \\
\hline
\end{tabular}


The diffusion rate of smart houses is still very low, indicating that they are in the very initial phase of diffusion. Diffusion studies have been carried out in various fields such as anthropology and social science. In the field of innovation management, Rogers proposed the theory of the diffusion of innovation. According to Rogers (1995), five factors were identified to affect the diffusion process. These were: 1) relative advantage; 2) compatibility (integration into existing systems); 3) complexity; 4) trialability (the extent to which a technology can be tried out); and 5) observability (extent to which potential adopters can see it in action). Rogers (1995) defined technology as a means of uncertainty reduction, recognizing that the software aspect is as important as the hardware aspect.

SSI (Sectoral System of Innovation), which was put forward by Malerba (2002), is defined as an innovation system comprising of a set of agents such as firms and non-firm organizations that carry out market and non-market interactions for the creation, production and sale of products in a sector. The knowledge base, source of technological opportunities, as well as the degree of cumulativeness and learning mechanisms differ across sectors. In addition, institutions, such as regulations, standards and the labour market, have a profound effect on SSI.

Besen (1995) analyzed the processes by which compatibility standards are established in the ICT industries and he pointed out several situations. Firstly, all sponsors may have common interests in the standard that is selected, so that they all prefer a mechanism that quickly and efficiently discovers which standard best serves those interests; this might be thought of as the 'technocratic' view. Secondly, the sponsors' interests may be directly opposed in that each wishes to make its proposed standard adopted by others, others they would prefer to have no standard set.

This outcome is likely when the benefits to the industry as a whole from having a standard are small relative to the differential gain obtained by the winner of a standards battle. Thirdly, each sponsor may prefer its own standard, but each would prefer another standard to none at all. This case is most likely when the gains from having a standard are very important - perhaps because consumers will delay their purchases if they are unsure about which standard will ultimately emerge.

Von Hippel (1986) proposed the importance of lead users in driving new product development. Lead users face needs that will be general in the marketplace, but face them months or years before the bulk of that marketplace encounters them. Lead users are positioned to benefit significantly by obtaining a solution to those needs.

\section{TECHNOLOGY AND STANDARDIZATION}

\section{ECHONET AND KNX}

\section{A. Technology standards of smart house}

ECHONET was established in 1997 as a voluntary standards body to set the standards for home networks. As of February 2015, 252 companies are members of the ECHONET Consortium. Eight companies are members of the decision making body, which include Sharp, Tokyo Electric Power, Softbank Telecom, Toshiba, NTT, Hitachi, Panasonic and Mitsubishi Electric. ECHONET Lite has been approved as a de jure standard by METI in February 20127. Parts of ECHONET Lite have been certified as a standard by IEC, and the remaining is expected to be certified by ISO/IEC JTC1 as a standard.

ECHONET Lite is the standard for appliances, which can be grouped into eight types. In Table 3, the eight categories of the appliances are shown. For example, in Group 1, sensors would include a sensor to detect the level of water in a bathtub and even a snow sensor.

KNX was established as a merger of the three organizations EIB, EHSA and BCI in 1999. The official name of KNX is 'Worldwide Standard for Home and Building Control'. 364 companies produce $\mathrm{KNX}$-certified products. KNX is a profit-making organization due to the certification business accomplishing an annual turnover of 500 million yen. KNX has 43 branches worldwide, having just set up one in Japan in February 2014. 
According to information obtained from the interviews, KNX's ranking of applications are as follows: 1) lighting; 2) blinds; 3) monitoring; 4) HVAC; 5) remote control; 6) security systems, 7) energy management, 8) metering, 9) audio/video controls, 11) white goods. The low ranking of white goods indicates that KNX is putting more emphasis on infrastructure and large-scale solutions, such as smart community management or building management. Compared to ECHONET which is focusing on smart houses, KNX is putting emphasis on city solutions, such as smart buildings, which are part of a smart city.

\section{B. A comparison of the strengths, weaknesses of ECHONET Lite and KNX}

Through the interviews, ECHONET Lite was found to have several advantages. First, the range and depth of the standard were pointed out by several interviewees. For example, ECHONET includes functions such as control of temperature as well as blinds. Another advantage of ECHONET is its openness, since the standard and the tools can be downloaded free of charge. Such openness reveals the ECHONET management's strategy to put priority on the diffusion of smart houses. In the case of KNX, the specifications, the handbook, and the tools are sold for about 1000 euros. The standard-setting procedure of ECHONET is based on a technocratic approach, as pointed out by Besen. The eight leading companies have the voting rights, while all members of the consortium have the right to make a request towards the standard setting. However, only the managers of the eight companies can take part in the Board of Directors meetings, which make the important decisions. A feature of ECHONET is the comprehensive, detailed standard.

On the other hand, there are some issues of concern for ECHONET. Unlike KNX, the specifications for the standard are distributed free of charge, so that profit motives for ECHONET are rather low. Operations of the certification support centre are funded by government's subsidies so that obtaining funds for operation in the future may become a problem. Up until now, ECHONET has not played a leading role in the diffusion of smart houses, leaving such activities to the companies in the consortium.

ECHONET has been developing and providing software tools for the development of ECHONET Lite-compatible products. During an interview, the developer of Open ECHO at Sony CSL (Computer Science Lab) pointed out that although he developed the API for smart houses in an open source environment, it has been difficult to find users who can do the debugging. For smart houses, various appliances and consumer electronic products made by different vendors have to be connected and such combinations are countless. A single company cannot do the development on its own; one would expect the users to do the debugging in an open source environment. The lack of an active user community for ECHONET might become a problem, making it difficult for them to gain dominance as a de facto standard. ECHONET has recently set

Table 3.

Categories of the appliances for ECHONET

\begin{tabular}{ll}
\hline Group & Goods \\
\hline Group 1: Sensors & $\begin{array}{l}\text { Gas, Security, Sound, Earthquake, Lighting, Air, CO2, Water, Human movement, } \\
\text { Humidity, Smoke }\end{array}$ \\
$\begin{array}{l}\text { Group 2: Ventilation } \\
\text { Group 3: Convenience for the } \\
\text { home }\end{array}$ & $\begin{array}{l}\text { Air conditioner, Humidifier, Electric carpet, Ventilator, Fan heater, Unit cooler } \\
\text { Battery, Fuel cell, Smart meter, Smart gas meter }\end{array}$ \\
$\begin{array}{ll}\text { Group 4: Cooking and other tasks } \\
\text { in homes }\end{array}$ & Cooking heater, Coffee maker, Washing machine, Dishwasher, Refrigerator \\
Group 5: Healthcare & Blood pressure meter, Thermometer, Weight scales \\
Group 6: Controller & Switch, Mobile terminal \\
Group 7: Audio Visual & TV, Display \\
Group 8: Electric Vehicles & EV, PHV (To be considered) \\
\hline
\end{tabular}


up a certification support centre in Malaysia, as besides Japan, ECHONET has been aiming at gaining presence in East Asia. According to the interviews, the preference of Asians is similar to the Japanese. Asians prefer to be able to monitor and control consumer electronic devices at a detailed level. In order to control devices at such a level, multi-functional consumer products are necessary. The strengths of KNX are related to KNX's strategy to focus on infrastructures, as put forward by its concept of the KXN city. A smart building would contain KNX applications and KNX devices, which are the components of a smart city

KNX considers that each company belonging to the KNX association has its own strategy; some are in $\mathrm{B} 2 \mathrm{~B}$ business while some others are in the B2C business. In contrast to METI which has a list of eight priority products that it is trying to promote, KNX lets the companies decide which products to promote. As pointed out by the KNX chairman in an interview, "The companies can position the product in the market in the best way they would like to do".

Compared with ECHONET, KNX's standard-setting procedure is more rigorous and highly structured. According to the Chairman of $\mathrm{KNX}$, "Standard-setting is done in the working group, under the umbrella of KNX Association. Technical matters are discussed in the Technical Board and then they will be agreed upon for finalizing it. Then the Marketing Board will fix it up to tool area. Yes, it has to be fixed up, what has to be done in the tool. The tool cannot stay as it is, there has to be some adoptions to new functionality and new alignment on IT structure". KNX has put emphasis on interoperability. According to the interviews, "KNX standard has a specific structure behind it. Its mechanism is event-driven, not polling-. Specific transition/ transmission protocol is defined. Things are fixed at the end of the day, because we have to guarantee all our members and all our customers that we are download-compatible. So we have to maintain some basics." So in the case of KNX, download compatibility and interoperability are guaranteed at the system level. However, the interviews have confirmed that KNX's focus on
B2B and building management also indicates their weaknesses with regard to smart houses. The lack of presence of competitive white goods consumer electronic makers is another problem. Unlike ECHONET, which has a detailed comprehensive specification for consumer electronic products, KNX's standards are relatively weak.

\section{THE STRATEGY OF THE MAIN ACTORS}

\section{A. Toshiba}

Toshiba has played a pioneering role in the development of home consumer appliances connected to Internet. In 2002 the company started its FEMINITY line of products which include home appliances such as washing machines, refrigerators, microwave ovens which can be controlled by IP. Since ECHONET already existed, Toshiba decided to use the ECHONET standard. The Internet had not diffused by then, so Toshiba was an early starter. At that time, the FEMINITY line of refrigerators was priced at 300,000 yen, electric ovens 200,000 yen, and air conditioners 300,000 yen. It was a radical innovation, since Toshiba was able to achieve the world's first in providing home appliances connected to Internet that could be controlled. However, the products were too expensive for the ordinary customers, sotheir FEMINITY line of businesses did not grow. According to Toshiba, they were 10 years too early to launch such products. However, unlike Toshiba's competitors which had entered the business, Panasonic in 1999 and Hitachi in 2004 but later exited, Toshiba was able to continue their FEMINITY line of business as the company changed its strategy by collaborating with largescale construction companies. For example at a building complex called Kawasaki Lazona, the condominiums were pre-installed with Toshiba's FEMINITY-line security system and other appliances when they were put on the market. Toshiba has a long history of making ECHONET-ready products - in other words, products which can be made ECHONET-compatible by connecting adapters. This is where there has been a need to establish standards. Standards have to be set in order to connect the adapters to the various 
products. Since 2004, if one purchased a Toshibamade air conditioner it was possible to control it through ECHONET by connecting it to an adapter.

In the case of Panasonic and Hitachi, the products offered by both companies were based on their own interfaces, not standards (further research is necessary to analyze why these two companies exited). Toshiba has adopted an open strategy from the initial phase of entering the smart house business.

The FEMINITY line of HEMS is based on a cloud-type HEMS. Unlike NEC or Panasonic, which had a centralized control unit in their main modules of HEMS, Toshiba has chosen a different strategy based on their preference to adopt an open approach under the belief that no single company will be able to be a dominant player in the smart house field. Their early decision to use ECHONET back in 2002 when they entered this business also reveals their strategy.

\section{B. NEC}

NEC has been known for its Computers and Communications $(C \& C)$ business for many decades. The company's mission has been to provide Society's Solution business in the areas of the public sector, enterprises, telecom carrier and smart energy. The company aims to be globally active in social infrastructure innovations through ICT, based on its long-term market and technological competences. NEC has competencies in Next Generation Networks, high-quality, highreliability IT and communications technologies, devices, sensors and human interface technologies. The company has been allocating resources in key sectors such as transportation, space, satellite communications, undersea communications, digital medical record, e-government and smart energy. NEC's cloud service business has been growing rapidly. HEMS is one of the services which are provided over their cloud service. Such services require capabilities in big data, device control, device access, security, maintenance, scale up and multi-tenant technologies. NEC has developed a cloud service platform called CONNEXIVE, which has been used by their smart energy business to provide Cloud-type Energy Management Service. NEC is one of the members of the HEMS Alliance, which also includes Toshiba, Hitachi, Mitsubishi Electric, Panasonic, Tokyo Electric Power and KDDI, all of which are working on the joint development of an infrastructure to develop applications for HEMS. HEMS consist of many different components and modules. NEC has been competitive in batteries, so this has been the company's key component in HEMS. The battery storage system is equipped with a centralized control unit, unlike Toshiba's HEMS products which are based on an open strategy. NEC's HEMS products are high valueadded products, suitable to function as a Home Energy Manager. For example, by extracting and analyzing the data of the customer's behaviour such as electricity usage in real time, NEC's HEMS can provide their customers with valuable energy-saving recommendations. This is quite different from the low-end HEMS, which only shows a home's energy consumption in real time.

NEC has also been involved in smart meters. In Japan, the meters used in homes are expected to be replaced by smart meters within the next ten years. The market for smart meters is closed with strict regulations, making it difficult for new entrants to enter the market, mainly because of the need to take tight security measures. A smart meter consists of two parts: the measuring device and the communications part. NEC has been actively involved in the smart meter business for the latter part, which is based on their core competencies in communications. As the network topology changes every year, it is expected that NEC will be able to capitalize on their network design capability to expand their business in smart meters.

The analysis has revealed that NEC has been acting according to its vision: 'Connected House/Home through IoT/M2M'. The company has been working together with other companies such as Orix in their battery rental business, and Sekisui Heim (a house company) for promoting their HEMS business. In the former case, Orix has been providing NEC with financing. In the latter case, they are popular among the customers 
since they can recuperate the investments within seven years, using subsidies.

The case of NEC's strategies illustrates that the company is trying to strengthen its presence in smart houses by building on its accumulated core competences in communications, cloud services, by focusing on key parts of the smart house, such as smart meters, batteries and high-end HEMS. The company has been eager to form joint ventures to accomplish their strategies.

\section{METI's strategy}

The main concerns of METI are 1) to nurture the industries and support the economic development and 2) to obtain sufficient energy for Japan. Since 3.11 (the major earthquake in the North Eastern area), there has been a change in requirement for energy-saving in Japan, from the emphasis on energy-saving through hardware-based solutions by diffusion of energy-saving equipment, to energy-saving based on efficient and 'smart' solutions, or in other words, 'software'-based solutions.

A variety of types of equipment and appliances exist in a house, all of different make, which have to be connected to one another in a smart house. Hence, the role of standards becomes valuable. In November 2011, a decision was made in the Energy and Environment Conference to standardize the interfaces between the smart meter and HEMS in order to promote the diffusion of HEMS. It was decided to use ECHONET Lite for the standard between HEMS and the smart meter in February 2012.

By setting such standards, METI expects three positive outcomes:

1. that the use of smart meters and visualization of energy consumption will lead to energy saving;

2. that through interoperability, enabling different products/equipments made by different makers to be linked, a variety of new energysaving services will be made possible;

3. that in addition to the large companies which are the main players of smart houses, smalland medium-sized companies and venture companies will enter the market.
The HEMS taskforce within the smart house/ building White Good (WG). has been working on setting the standards for the API between the service providers. The smart meter taskforce within the WG has been concerned with setting standards between the smart meter and the HEMS appliances.

METI has announced a set of eight highpriority product/appliances which include: smart meters; solar power panels; batteries; fuel cells; $\mathrm{EV} / \mathrm{PHV}$; air conditioner, lighting; and boilers.

Figure 1 shows how the various components are connected in their vision to promote smart house/buildings. METI expects that new services will emerge based on the HEMS platform.

At METI, the Information Economy division in the Commerce and Information Policy Bureau has been the main unit in charge of promoting smart houses/smart buildings. Another unit in the Agency for Natural Resources and Energy, the Electricity Market division, has been playing a supportive role.

The smart house/building WG has been concerned with six issues:

1. setting the lower parts of the high priority areas;

2. preparation of the operating manual;

3. testing the connectivity with other appliances and certifying the product;

4. strategies for international standards;

5. analysis of DR (demand response) technologies and standards;

6. promotion of new businesses by using HEMS data.

METI points out that for effective energy management, aggregators which aggregate the various demand made by the houses/homes, condominiums, buildings etc. through IT and cloud will play an important role. In the case of MEMS (Mansion (condominium) Energy Management System), new players such as equipment makers, telecom operators and CATV operators have entered the market as MEMS aggregators last year, when METI chose 24 companies from the applicants which applied for funding. For those companies, METI provided subsidies to cover 


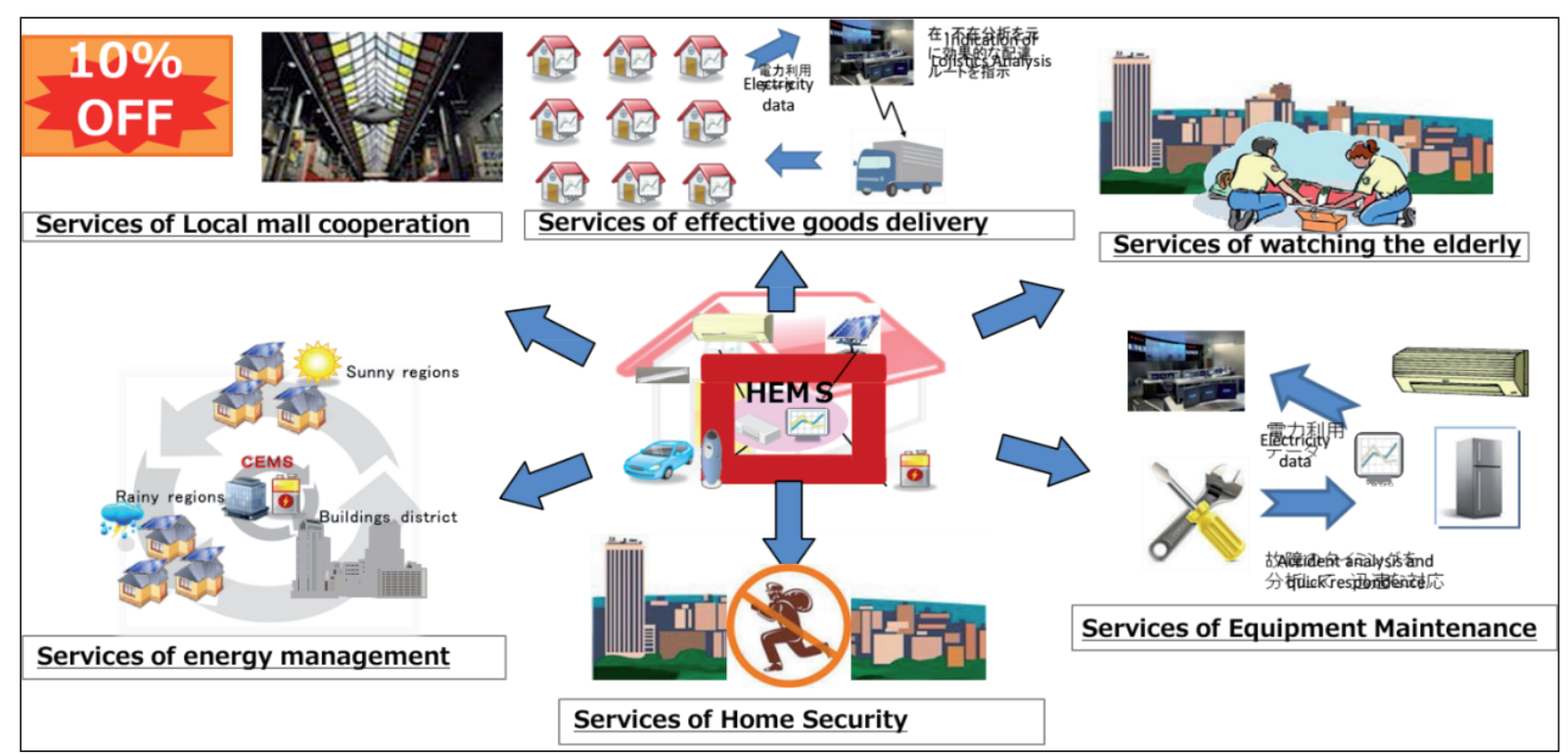

Figure 1. METI's view of HEMS (Adapted from the presentation given by T. Tateishi, METI on 11/18/2014)

one-third of the cost. From the perspective of METI, the main purpose of promoting HEMS is new business creation, so that new service providers that use the data collected and managed by the aggregators may emerge. METI has allocated 4 billion yen for the large-scale HEMS project.

However, such new service creation may lead to social problems such as privacy. As electricity usage data will be shared by different service providers, how to deal with privacy protection has become a new concern for METI.

\section{Yokohama City's case}

At present, Yokohama has been doing a demonstration project in becoming a smart city which has been funded by METI. Yokohama City has been one of the four cities where trial demonstrations have been taking place. Toshiba and Tokyo Electric Power play a key role in this trial. Yokohama City has been in charge of the whole project, Toshiba has been the leader of the CEMS and HEMS working group, and Tokyo Electric Power has been in charge of the power grid network and the modules and system backup. 4000 homes and other buildings such as a local hospital have taken part in the demonstration project. A HEMS unit made by either Toshiba or Panasonic, which normally costs 100,000 yen, have been distributed to the 4000 houses by using a subsidy so that the home owner only had to pay 10,000 yen. The electricity which has been generated by co-generation at a hospital has been supplied to other buildings in the community. Yokohama has been known in general for the citizens' enthusiasm towards energy saving. In the past, Yokohama has been able to achieve a $40 \%$ reduction in waste disposal due to the citizens' efforts.

In order to attract the home owners to join the experiment, Yokohama City adopted three approaches, one which was based on normal information provision, another which was based on providing more detailed information, and a third which was based on providing detailed information as well as special incentives, such as coupons. It was observed that as they changed the pattern towards the third type, the percentage of people who decided to join the experiment, as well as the energy savings in the homes, increased.

Yokohama City used to consider that installing HEMS in homes and allowing the family members to check and see the energy usage in real time mode was the purpose of HEMS. However, through the experiment, Yokohama City's managers of this project learned that it was important to stress the importance of HEMS from the point of view of being able to provide a new value to the home owner, in terms of controlling electric appliances or managing energy usage. 
Hence, HEMS is a product which requires intensive technology marketing, interacting closely with the customers to explain about the new value added. If one can persuade the customers who are concerned about the price of HEMS about the benefits and the value added, then HEMS diffusion should pick up momentum. Currently the diffusion of HEMS has reached 100,000 houses in Japan. If it reaches $1,000,000$, then the market might grow without subsidies. In the early days, the marketing of HEMS tried to emphasize the merits of $10 \%$ energy savings, but it could not be confirmed in the trial. The energy savings have been driven mainly by home owners purchasing new consumer electrical appliances which are more energy-saving, having been able to visualize the electricity usage in real time mode. Thus the energy-saving merit seems to be more limited than expected.

\section{CONCLUSION}

The technology and standardization strategies of the main actors related to smart houses in Japan has been examined, and a comparison with the European case was made. Eleven interviews were carried out in Japan and Germany. The main findings are as follows. The differences in strengths and weaknesses between the standards in Japan and Europe were identified. KNX's strategy has been to focus on infrastructures and city solutions, while ECHONET has been focusing on smart houses. The strategies of the main actors, such as the ECHONET Consortium, Toshiba, NEC, METI, the government, and Yokohama City, the local government, towards smart houses have been diverse, based on the actors objectives, missions and their accumulated core competences. Toshiba has a long history of making ECHONET-ready products since 2002. NEC has been focusing on a cloud-based energy management system as well as smart meters based on their core competences in communications and cloud services. As a smart house consists of many modules and components, technologies which have to be integrated, companies have been focusing on one part of the system.

The METI are interested in promoting HEMS from the point of view of new business creation. The trial demonstrations which have been taking place in Yokohama city revealed that HEMS is a product which requires intensive technology marketing, including interacting closely with customers to explain about the new value added. The energy-saving merit of HEMS used in marketing HEMS seems to have been over-valued. The lack of understanding of the user's need, or the potential need seems to be a problem which must be overcome to speed up the diffusion of smart houses. A comparison of ECHONET and KNX highlighted that KNX was ahead of ECHONET in terms of globalization as well as marketing. Although ECHONET is planning to set up a certification centre in Malaysia, it would be a challenge to match KNX's presence in European countries as well as other parts of the world such as China.

\section{ACKNOWLEDGEMENTS}

We are grateful to the many people from industry, government and ECHONET Consortium and $\mathrm{KNX}$ who took part in the interviews.

\section{ENDNOTES}

1 Use Home Kit-enabled accessories with your iPhone, iPad and iPod touch. Retrieved from: https://support.apple.com/HT204893

2 経産省、大規模HEMS情報基盤整備事業 の交付を「iエネ コンソーシアム」に決 定--2年連続で [METI Decision to provide funding for Large scale HEMS project to iEnergy Consortium]. Retrieved from: http:// japan.cnet.com/news/business/35064139/

3 WG for Smart House standardization report abstract. Retrieved from: http://www.meti.go.jp/ committee/summary/0004668/011_04_01.pdf ECHONET Consortium. Retrieved from: http:// echonet.jp/

5 Zig Bee Smart Energy. Retrieved from: http:// www.zigbee.org/zigbee-for-developers/applicationstandards/zigbeesmartenergy/

6 KNX Community. Retrieved from: http://www. knx.org/knx-en/community/ index.php

7 TTC/NICT共催セミナー「HEMS普及に 向けた標準化について」[TTC/NICT joint seminar Standardization towards Diffusion of HEMS]. Retrieved from: http://www.ttc.or.jp/ maedablog/2015/20150223/ 


\section{REFERENCE}

Besen, S. (1995). "The standards processes in telecommunication and information Technology", in Standards, Innovation and Competitiveness: The Politics of standards in natural and technical environments, Edward Elgar, Cheltenham, pp.136-146.

Miyazaki, K. and Kijima, K. (2000). Complexity in technology management; Theoretical study and case study of automobile sector in Japan, Technology Forecasting and Social Change, 64(1), 39-54 http://dx.doi.org/10.1016/S00401625(99)00072-4.

Miyazaki, K. and Oshima, H. (2010). An Empirical Analysis of Technology Strategies of Leading companies related to Standardization in the case of Wireless telecom systems, JSICR (Japan Society for Information and Communications Research), 28(3), 65-76.
Malerba, F. (2002). Sectoral Systems of Innovation and Production, Research Policy, 31(2), 247-264. http://dx.doi.org/10.1016/S00487333(01)00139-1.

Porter, M. and Heppelmann, J. (2014). How smart, connected products are transforming competition, Harvard Business Review, [Online]. Available: https://hbr.org/2014/11/how-smart-connectedproducts-are-transforming-competition.

Rogers, E. (1995). Diffusion of innovations, The Free Press, New York.

von Hippel, E. (1986). Lead Users: a source of novel product concepts, Management Science, 32(7), 791-798 http://dx.doi.org/10.1287/ mnsc.32.7.791. 